\title{
Cytolytic Process
}

National Cancer Institute

\section{Source}

National Cancer Institute. Cytolytic Process. NCI Thesaurus. Code C61553.

Any cell death process resulting from rupture of cell membranes and loss of cytoplasm. 